\title{
Punctuation Marks and Translators’ Naïve Mind
}

\author{
Elena O. Kondratieva* \\ Buryat State University \\ 24 a Smolin Str., Ulan-Ude, 670000, Russia
}

Received 02.04.2018, received in revised form 28.05.2018, accepted 05.06.2018

Written translations often show that translators do not differentiate between punctuation systems and their conventions in different languages or communities, regarding punctuation marks only as formal separators. Unlike them, we consider these para-graphemes as important constituents of the semantic and logical structure of a text following rules that differ from one language to another.

This article tries to study how translators evaluate their proficiency in punctuation of their both native and foreign languages, and how crucial they think punctuation marks are in terms of written translation. The study subjects are professional translators and those who sometimes provide translation services. We collected their opinions through a Google Forms multiple-choice questionnaire consisting of 15 items on attention that translators pay to punctuation arrangement; a role of punctuation marks in encoding and decoding a message; frequency of punctuation challenges in translation; and awareness of punctuation features of the involved languages.

The results show that misconception of the functional potential of punctuation as a system is caused by lack of the necessary knowledge, which results from wrong assurance in one's proficiency in punctuation; and this misleading assurance is explained by that misconception of punctuation. Therefore, we need to turn this naïve point of view to a scientific angle by helping them to understand the actual role that punctuation can play in a text.

Keywords: translation, semiosis, naïve mind, language proficiency, translator's native language, punctuation marks, formal separators, punctuation mistakes.

DOI: 10.17516/1997-1370-0281.

Research area: linguistics.

\section{Introduction}

Considered as a secondary and supportive system within a language, punctuation is often underestimated. In particular, those who keep away from any linguistic researches but who work with a language every day, like translators, journalists, copywriters, advertisers, etc., often disregard punctuation rules. This results in plenty of news articles, advertisements, online materials that obviously need a scrupulous editor.
In the meantime, we perceive any signal from the outer world in a "batch mode", i.e. as a wholesome matter, with simultaneous activation of various processes of semiosis (Dashinimaeva, 2018: 18). Therefore, punctuation arrangement of a text comes from our ability to think in a system manner. That means the ability to treat a text as a comprehensive sign, a microsystem, not just a bunch of unrelated elements. Being part of such microsystem, punctuation marks, though short of

(C) Siberian Federal University. All rights reserved

* Corresponding author E-mail address: yelenaivankina@gmail.com 
substantive meaning, can involve into the logical structure of a text. That is to say, they express relationships between lexical elements.

Punctuation performs various functions: semantic, syntactic, expressive, style-defining. Since N.S. Valgina assumes that any phrase aims to express a message, she considers the semantic principle as primary functions of punctuation marks (Valgina, 1979: 7). N.N. Orekhova specifies that, in certain contexts, punctuation marks help to differentiate the meaning of a phrase (Orekhova, 2001: 34). Thus, these marks are crucial when it is necessary to disambiguate the meaning, especially in languages like English, which does not have plenty of word forms like Russian. Indeed, it is obvious that there are mistakes affecting - though sometimes only slightly - communicative and pragmatic effect and mistakes that only affect the language norm.

Still, we are certain that expertise in punctuation is part of language skills that any qualified translator should possess, whether they deal with clinical protocols, global website contents or fine literature. We assume that in terms of punctuation, they should always follow the conventions accepted in a community they work for.

\section{Statement of the problem}

We developed this survey as part of our study of reverse punctuation transfer in translation as we realized that, apart from lack of deeper knowledge in punctuation systems of both native and foreign languages, one of the factors of such transfer is a translator's assurance in their expertise in the area that turns to be misleading.

Therefore, we decided to gather translators' opinions on how crucial punctuation is when it comes to translation process, to explore how they evaluate their own expertise in punctuation, and to subsequently compare the results with the actual works of some of them. This way we explicate what their naïve mind (everyday consciousness) related to a punctuation literacy is like, and whether it coincides with corresponding scientific mind. Here, it is significant to note that naïve mind does not have anything in common with the meaning "simple-heartedness" or "ingenuousness".

\section{Participants and data collection}

The opinions on the role of punctuation in the translation process were collected through the Google Forms online solution, where we created a multiple-choice questionnaire. 13 questions in the initial version considered the importance of punctuation in translation, similarity of punctuation systems in the languages the responders work with and their proficiency in them, and the subjects' usual punctuation strategy. In the last item, we asked the translators to choose a variant with correct punctuation arrangement of a Russian sentence as an expresscheck of their knowledge.

Later, as we realized it was not valid enough just to get yes-or-no answers on usage of any reference guides, we added two points more to ask the responders to provide their references on punctuation for both languages.

The subjects of the present study were professional translators, and those who studied any international language and translation as their major at a university and now perform translation "from time to time" on a freelance basis or as part of their job. All of them were Russian native speakers. The total amount of subjects was 31, with more than one third of them being our colleagues whose everyday work is available for us to evaluate.

The experience in translation was as follows: 3 to 5 years for $35.5 \%$ of the respondents; $32.3 \%$ of the subjects claimed to have been in the industry for more than 10 years; $19.4 \%$ of them mentioned 5 to 10 years; and $12.9 \%$ of the 
translators have only been providing translation services for less than 3 years.

Most of responders reported to work with English (77.4\%), $9.7 \%$ of the subjects work with Chinese. Others indicated German, French, Buryat, or both English and Chinese.

\section{Results and discussion}

Although most of responders say they always pay attention to the punctuation arrangement of a text, some responders claim they only pay attention to how a text is punctuated "sometimes" or "when they have enough time for that". At the same time, as an answer to the question "How often do you find it complicated to choose a punctuation arrangement?" $12.9 \%$ of the subjects chose the "I don't pay that much attention to punctuation marks" variant. Speaking about how often they stop and think whether a punctuation mark is used correctly, some of the answers provided were "when I have time for such trivialities" (16.1\%), "sometimes" and even "never". However, we consider a text as a comprehensive sign with its elements - including punctuation marks - working on creating and, subsequently, uncovering the message, the idea within. Therefore, to ignore punctuation arrangement of a text means, more often than not, to miss a part of its meaning.

Most of the participants (80.6\%) say they "sometimes" face difficulties with punctuation arrangements. Nevertheless, only $6.5 \%$ of the informants report they regularly address a reference to choose this or that punctuation mark. The most popular variant to the question "How often do you address any guide to determine the correct punctuation mark?" was "only if I am sure I don't know the respective rule" (41.9\%), while others indicated they "sometimes" (29\%) or "never" (22.6\%) use references.

Almost every one of those asked to provide any references on Russian punctuation mentions guides by D.I. Rosental, A.E. Milchin and L.K. Tcheltsova, and V.V. Lopatin et al., as well as gramota.ru website, while more than $50 \%$ of the respondents claim they do not use any references or guides on punctuation in their foreign language. As many as $36 \%$ of the subjects pointed out Google Search and "various internet resources", and only one person named The BBC Style Guide.

Why do we need to have these sources at our fingertips? First, it is a matter of consistency. Consider English: not only British punctuation differs from American; there are two major Style Guides in the US - The Chicago Manual of Style (CMS) and The Associated Press Stylebook $(A P)$ - that have quite a few differences. For example, the $C M S$, used by book publishers and writers, recommends no spaces around emdashes and puts book titles in italics, while news media and journalists-specific $A P$ uses a space before and after an em-dash within a sentence and puts the book titles in quotes (The Associated Press Stylebook; Straus, Kaufman, Stern, 2014).

For example, in America, it is important to use one of these manuals, with different entities demanding to follow whether $C M S$ or $A P$ conventions. Thus, when writing an article, it appears that you should indicate which of these two you used in the case (a conversation with an ESL teacher H.A. Harr on March 9, 2018).

Moreover, we need to understand the logic of punctuating a text in both languages, which often differs from one another, i.e. different reasons for putting this or that mark, following different patterns and conventions accepted in these languages. That is why it is not relevant either that $41.9 \%$ of the subjects think they know punctuation rules of their foreign language "well" and "know where to find the information". This, as we discussed right above, turned not to always be true: 5 of those who indicated they use specific references on punctuation rules, later 
provided none of them when they were asked to. Furthermore, $54.8 \%$ of them say they are only familiar with "most common rules, but never took a closer look at the aspect". None of the subjects ever studied punctuation of their foreign language as a particular point.

This lack of expertise leads to irrelevant decoding of punctuation arrangement of the original text and further prorated transfer to the translation. This finally means, moreover, irrelevant awareness of the logic of the both texts. Formal similarity of punctuation marks in different languages makes a translator believe they have similar meanings and thus, similar functions in the given languages, which is far from truth.

As for their native language, $67.7 \%$ of the informants believe they know punctuation rules "well, i.e. know all the rules needed to complete translations, with rare challenges". As many as $16.1 \%$ of them indicated the "excellent" level, which meant to be "familiar with the majority of challenging cases" and "almost never use a reference guide". Almost $13 \%$ of the responders admit the "sufficient" level of expertise in punctuation, i.e. "the most common rules and usage cases". Still, one responder said they "don't think one should make too much of punctuation" at all.

In the meantime, our day-to-day collaboration with part of these subjects shows that not only they cannot "decode" the accent that a punctuation mark brings into a written fragment in a foreign language, but they also make frequent mistakes in their translations into native language, including those due to punctuation transfer.

The possible explanation is, of course, that they simply ignore punctuation and just automatically transfer those marks from the original to their translations. However, we could also consider this to result from translators' inability to "read" punctuation marks properly i.e. as signs with their own meaning - that is to realize the real value of them, and, therefore, their full functional potential in building the meaning of a phrase and expressing the message of a text.

The following fact also supports the statement above: while $61.3 \%$ of the informants admit punctuation marks "usually represent an integral part of the meaning of a text" (with $12.9 \%$ of the subjects thinking these marks "don't usually influence the meaning"), $25.8 \%$ of them claim punctuation marks "only act as formal separators and never influence the main idea". We consider such point of view as hardly acceptable for a person whose work is so closely connected with semiosis and language signs and who must treat every element of a language as an important element of an integral system.

Overall, we can see that most of the translators participated in this survey feel quite sure about their knowledge in punctuation, considering they know enough to perform their duties. Can we consider those optimistic answers as confirmation for the responders' high proficiency in punctuation? Unfortunately, this is not the actual state of matters. That is to say, their naïve mind is improper: translators do not fully realize they are not familiar with all the needed punctuation rules, or, probably, are not aware of the fact some of these rules do exist.

For example, those colleagues who claim they know punctuation rules well enough, the idea of our study, to some extent, developed as we observed their day-to-day performance, because they've been making punctuation mistakes rather often when translating to their native language, nothing to say of their English texts (Kondratieva, 2017). In fact, it was their written translations from English to Russian we used to develop our first classification of punctuation mistakes due to reverse transfer. 


\section{Conclusion}

Compared to the real performance of several respondents, the results allow us to consider a translator's misleading assurance in their expertise as a factor of their inadequate awareness of the necessary conventions and punctuation usage rules, as well as the consequence of their lack of deeper understanding of the role and functions of punctuation marks.

So far, it looks like an endless circle: a translator does not understand punctuation as a system with its own functions beyond serving as formal separators, because they are short of the necessary knowledge. They do not strive for these knowledge as long as they are sure (however, inadequately) they know enough of punctuation's functional potential. In turn, this assurance is driven by the fact mentioned first, which is lack of understanding. As a way to release from the circle and to prevent this naïve point of view in prospective translators, we would offer presenting punctuation as a system that is not universal, but is language-specific not only in terms of the formal layout, but in terms of the deeper, logic and semantic level. In other words, our objective is to try to substitute content of a translator's naïve mind with the one of theoretical (scientific) mind.

As for those who already became part of translation industry, apart from continuous gaining their field-specific knowledge (e.g. in healthcare, economics, chemistry or advertisement), it is obvious that translators should always train themselves in terms of languages, both first and second (third, etc.). We would only specify: they should also take care of their expertise in paragraphemics, keeping in mind one of the famous paradoxes, "All I know is that I know nothing".

\section{References}

Dashinimaeva, P.P. (2018). Teoriia perevoda: psikholingvisticheskii podkhod [Theory of translation: a psycholinguistic approach]. Ulan-Ude, Izdatel'stvo Buriatskogo gosuniversiteta, $360 \mathrm{p}$.

Kondratieva, E.O. (2017). Punktuatsyonnye oshibki v perevode, obuslovlennye obratnoi interferentsiiei inostrannogo iazyka na rodnoi perevodiashchii iazyk [Punctuation mistakes in translation due to reverse transfer from a foreign language to a native target language], In Problemy teorii, praktiki I didaktiki perevoda: Sbornik naychnykh trudov. Seriia [Proc. Problems of translation theory, practice and methods of teaching. Series]. Nizhnii Novgorod, NGLU, 20(1), 117-124.

Orekhova, N.N. (2001). Punktuatsionnaia Sistema iazyka: formirovanie I dinamika razvitiia: dis. dokt. filol. nauk [Punctuation system of a language: formation and dynamics. PhD Thesis]. Voronezh, 292 p.

Straus, J., Kaufman, L., Stern, T. (2014). The Blue Book of Grammar and Punctuation. SanFrancisco, Jossey-Bass, A Whiley Brand, 201 p. Available at: https://www.grammarbook.com (accessed 31 March 2018).

The Associated Press Stylebook (2018). Available at: https://www.apstylebook.com (accessed 31 March 2018).

Valgina, N.S. (1979). Russkaia punktuatsiia: printsipy i naznachenie. Posobie dlia uchitelei [Russian punctuation: its principles and role. Teachers' manual]. Moscow, Prosveshchenie, 125 p. 


\title{
Пунктуационные знаки
}

\section{и наивное сознание переводчика}

\author{
Е.О. Кондратьева \\ Бурятский государственный университет \\ Россия, 670000, Улан-Удэ, ул. Смолина, $24 a$
}

\begin{abstract}
Часто в письменных переводах можно отметить, что выполнявщий его переводчик не разграничивает пунктуачионные системы своих рабочих языков, не осознает, что соответствуюшчие конвенции, принятые в сообществах носителей этих языков, могут различаться. Многие переводчики полагают, что знаки препинания выполняют лишь формальную разделительную функиию. В отличие от них автор считает, что эти параграфемные средства являются важной составляющей семантико-логической структуры текста, а правила их употребления разнятся от языка к языку.

В данном исследовании автор попьтался выяснить, как переводчики оченивают свои знания пунктуачионных систем родного и рабочего иностранного языков, как они оченивают роль пунктуационных знаков в письменном переводе. Информантами выступили профессиональные переводчики и те, кто иногда оказывает услуги по переводу. В качестве метода сбора информации взят опрос с множественным выбором ответа, составленный при помощчи сервиса Google Forms. Пятнадиать вопросов анкеты были посвящены тому, как часто переводчики обрашают внимание на пунктуачионную составляюшую текста, как они оченивают роль пунктуации в формировании смысла текста, как часто в их практике возникают трудности с пунктуированием, а также тому, насколько хорошо они знакомы с особенностями пунктуации рабочих языков.

Результаты исследования указывают на то, что недопонимание всего функционального потенциала пунктуации как системы следует из недостатка соответствуюших знаний, невосполнение таких пробелов в знаниях вызвано ложной уверенностью переводчика в достаточности его знаний, а ложная уверенность вытекает из недопонимания всех особенностей пунктуационной системы. Направить переводчика в сторону более научного представления можно, помогая ему осознать реальную роль пунктуации в тексте.
\end{abstract}

Ключевые слова: перевод, семиозис, наивное сознание, языковая компетенция, родной язык переводчика, пунктуационные знаки, знаки препинания, формальные разделители, пунктуационные очибки.

Научная специиальность: 10.02.00 - лингвистика. 